\title{
An African Diasporan Writer in Search of Language and Narrative Devices: An Exploration of Femi Adedina's Highway to Nowhere
}

\section{Femi Adekunle*}

Department of Theatre Arts, Adeniran Ogunsanya College of Education, Nigeria

\begin{abstract}
An African writer in the diaspora faces a dilemma that of how to tell his/her story and what language to use in the story telling. This challenge arises because the "diasporan" writer is one who has a story to tell in a language that is not his/her own to the owners of the language. The concerns are two-edged: telling the story in a way that meanings will be retained as conceived in his/her native tongue, the language he reasons in and presenting these thoughts in concrete forms utilizing a non-native target language in a manner that the owners of the language will be interested in the story. This becomes a necessity if $\mathrm{s} / \mathrm{he}$ wants the story to be a success. This paper therefore sets out to share the experiences and challenges faced when writing a new novel - Death's Laughter for a foreign audience using a foreign language that is not the writer's native language. It also explores the devices marshalled towards dealing with these challenges.
\end{abstract}

Keywords: African diasporan writer; Narrative devices; Foreign audience; Highway to nowhere; Bilingualism

\section{Introduction}

"The agony it was to switch from Russian to English... not only style but subject undergoes a horrible bleeding and distortion when translated into another tongue" - Vladimir Nabokov

To culture and communication are intertwined since culture not only governs communicators, the communication's content and processes but also shapes people's messages' encoding, meanings and communication's environment in relation to messages sending and interpretation... thus culture is communication's foundation [1]. Cultures "embed meanings which language reflects" and transfer during communication [2]. Language then serves as cultural transmission's vehicle since "any language has a dual character: it is both a means of communication and a carrier of culture" [3]. As a Yoruba writer in English, Highway to nowhere writer faces challenges such as syntax transfer, diction appropriation and second language interference. In the novel for example, there is the use of the Nigerian English variant, which is different from the standard written English. These challenges can be illustrated with the following examples. The novel's opening sentence, 'My father, a Reverend, like his father, a storyteller' could be rendered in English as, 'My father, a Reverend, like my grandfather was a storyteller'. The first sentence as written, however, is almost a literal translation of Yoruba sentence structure into English. The Yoruba sentence would have been written as, 'Baba mi, alufa, bi baba re je asotan'. Repetition of the word 'baba' in the Yoruba sentence is because Yoruba language does not have a single word that approximates to the English word 'grandfather'. The only Yoruba word that comes close in meaning to grandfather when translated is " $b a b a$ Àgbà but which means elderly father. Instead there is a phrase ' $b a b a$ baba mi' which translates into 'my father's father' or 'the father of my father'.

Diction was a problem while writing the novel-Highway to nowhere. Deciding on the appropriate word to capture Pastor Jude's father's and grandfather's functions in the novel's first sentence was difficult because of the variety of words expressing the type of functions the novelist had in mind for them as their community's wise men. The following Yoruba words connote someone who tells stories or whose roles include storytelling: opitan, asotan, akigbe, apalo, asunrara, akejala and akewi. These words could be translated as opitan - historian; asotan - storyteller; akigbe - chanter, herald; apalo - raconteur or one who tells stories and riddles during moonlight period; asunrara - a chanter of a particular oral poetry of the Yorùbás in Nigeria's Central region called rara; asunjala - a chanter of Yoruba hunters' traditional oral poetry and akewi - a traditional poet. Each of those italicized names has storytelling functions in their performances. The use of storyteller in the novel, (which in English language can also mean a fib merchant, a gossip or a liar) was an unconscious attempt at separating and particularising Pastor Jude's father's and grandfather's roles and expertise in their community. He could have used the word 'griot' but he substituted it with asotan - storyteller because that fits into what they will be called in Yoruba culture.

Another example is second language interference. Yoruba tenses are not as many as in English as the following Table 1 shows.

The underlined words in the Yoruba sentences are the verbs. Whereas the English verbs are morphologically marked for simple present and past (as in -ed and -s) and lexically marked for present and past as evidenced in phrases like 'is happening', 'has happened' and 'will happen'; the Yoruba verbs are generally lexically marked as demonstrated with the verb 'sele' meaning 'to happen'. To indicate time such as present and past, the verb 'sele' will need to be modified as in, 'o $\mathrm{n}$ sele (it is happening)', 'o tisele (it has happened)', and 'yoo sele (it will happen). In addition, we also have structures like 'o sele' in which case we may mean 'it happened' or 'it happens' depending on the adverb of time, which follows 'sele'. The list of such adverbs include' 'L'ana' yesterday, l'oni - today, 'lowolowo bayi' - this moment, 'tipetipe' - long time ago and 'l'ola' - tomorrow. These are some of the difficulties faced in writing the Highway to nowhere as a result of the differences between

${ }^{*}$ Corresponding author: Femi A, Department of Theatre Arts, Adeniran Ogunsanya College of Education, Nigeria, Tel: +234 1850 6038; E-mail: jibolaade@gmail.com

Received August 20, 2018; Accepted September 18, 2018; Published September 25,2018

Citation: Adekunle F (2018) An African Diasporan Writer in Search of Language and Narrative Devices: An Exploration of Femi Adedina's Highway to Nowhere. Arts Social Sci J 9: 404. doi: 10.4172/2151-6200.1000404

Copyright: (c) 2018 Adekunle F. This is an open-access article distributed under the terms of the Creative Commons Attribution License, which permits unrestricted use, distribution, and reproduction in any medium, provided the original author and source are credited. 


\begin{tabular}{|l|l|l|l|}
\hline Yoruba & Tense & English & Tense \\
\hline O sele lana & past & It happened yesterday & past \\
\hline O sele l'oni & present & It happens today & present \\
\hline O n sele lowolowo bayi & present & It is happening right now & present continuous \\
\hline O ti sele tipe tipe & past & It happened long ago & past perfect \\
\hline Yoo sele l'ola & future & It will happen tomorrow & simple future \\
\hline
\end{tabular}

Table 1: Comparison of Yoruba and English tense structures.

the novelist's thinking in the source language (Yoruba) and writing in the target language (English).

A literary work must first be conceived, and visualised in the writer's mind. It is most likely that the writer will create the world, the settings and the characters from within his/her cultural background. The greater part of the creative process and patterns may also be derived from the same milieu. Transiting from conceptualisation to words on paper is usually the next step in writing. This may be easier for a first language (L1) writer writing for L1 readers. The transfer and translations of thoughts, ideas, cultural motifs and icons of an L2 by a native speaker into a non-native language for the (L1) reader of the language can be problematic. This is because an L2 user like this novelist struggles to convey clear pictures and ideas to readers who may not have the tools of interpreting the pictures the writer is creating on paper.

The major challenge, however, occurs when an African L2 speaker of English, French or Portuguese tries to convey his/her cultural items or icons into these languages and finds out that they do not have equivalent cultural motifs or icons as his. This challenge, which he faced, is in how to transfer or adequately convey these motifs, ideas and issues from the Yoruba language, which is indigenous or L1 to him, to a language that sometimes does not have the words or phrases to express these concepts. He also faced the challenge of making issues, motifs and cultural icons real, plausible and possible in a language that is not second nature to him. The first set of challenges is highlighted above. The second comes in the ability and dexterity of the L2 with a language that is foreign to him/her. In his experience as an L2 user, this is reflected in the choice of the foreign language's diction, his attempts at manipulating and using the imagery that is native to the language, and often the way he used the foreign language's grammar, vocabulary and meanings. In trying to translate them, however, there is always a loss or sometimes a mutation or mutilation of the concept, icon or motifs being transferred.

The challenges facing L2 writers are glaring when one looks at African literature and African writers. The reason for this is not far fetched. African writers writing about Africa are writing from a background of colonialism. Colonialism as a system denied Africans their cultures and languages. The imposition of Western religions, culture, education and languages on African colonial societies, and the use of these in postcolonial times, has contributed in determining the worldview of the neo-colonial and postcolonial African writer. This situation makes the African writer a half-child, that is, one stranded at the crossroads - not knowing where to go or which language or imagery to use. The ability to craft stories in the indigenous motifs and transfer them into the colonisers' languages of French, English, and Portuguese is not really an advantage to the African writer but something confusing and problematic. Most African writers try to tackle these problems and some African scholars such as Ngugi, Chinwiezu, Wali and others, have even explored these problems.

\section{Using the Master's Language: Language and the African Literary Writer}

Caliban is stripped of his language in Shakespeare's The Tempest, and one may say taught Prospero's language. However, what he profited from learning the new language was being able to curse in a language that is $\mathrm{L} 2$ to him:

Caliban: You taught me language; and my profit on't is I know how to curse: the red plague rid you, for learning me your language! [4].

Shakespeare's portrayal of Caliban in the play, however, is germane when discussing language, power position and roles and relationships between the coloniser and the colonised, and the oppressor and the oppressed. Africans under colonialism, post colonialism and neocolonialism were and still are forced to learn the colonisers' languages and cultures. During colonialism, the languages were imposed and forced, and in post-colonialism the Africans who passed through the school systems and wanted to interact with the wider world had no choice but to use the international language. The reason is that African indigenous languages and cultures were demonised, treated as heathenish but also made to look inferior and unworthy. In the colonisers' classrooms, pupils were punished and shamed when they used their mother tongues even after independence from the Metropolitan powers. This continued as Ngugi [3] explains in his account that:

In Kenya, English became more than a language: it was the language, and all the others had to bow before it in deference. Thus one of the most humiliating experiences was to be caught speaking Gikuyu in the vicinity of the school. The culprit was given corporal punishment - three to five strokes of the cane on bare buttocks - or was made to carry a metal plate around the neck with inscriptions such as I AM STUPID or I AM A DONKEY. Sometimes the culprits were fined money they could hardly afford (p. 11).

Variations of the scenario above existed in most African nations, no matter who colonised them [5-7]. Furthermore, Ngugi shows that the colonisers and colonised peoples' attitude to English was the opposite of the colonisers' attitude to indigenous languages because:

Any achievement in spoken or written English was highly rewarded: prizes, prestige, applause; this was the ticket to higher realms. English became the measure of intelligence and ability in arts, the sciences, and all the other branches of learning. English became the main determinant of a child's progress up the ladder of formal education" (p. 12) [3].

Sadly though, this practice continues to this day in postindependent African countries. The continuous put down of African cultures and languages, coupled with depictions of Africans as barbaric savages and less than human, in many years of Europeans' writings about Africa deprived Africans and blacks of their dignity and integrity observes that $[5,8]$ :

The worst thing that can happen to any people is the loss of their dignity and self-respect. The writer's duty is to help them regain it by showing them in human terms what happened to them, what they lost. There is a saying in Ibo that a man who can't tell where the rain began to beat him cannot know where he dried his body. The writer can tell the people where the rain began to beat them (p.8). 
In order to carry out this onerous responsibility, the writer needs to use language that will convey situations and conditions appropriately to his readers and hearers, that is, his fellow Africans. The question is: what language will the writer use, the coloniser's or the writer's native language? This is a situation that becomes complicated, given that most African languages pre-colonialism were oral and unwritten. The colonisers - through administrative staff, missionaries, scholars and traders - developed orthographies for most African languages. So, when the writer writes in the modern version of his native language, he/ she is still in contact with the colonisers' influences, though indirectly.

This 'heads you lose, tails you lose' situation has faced many African writers since colonial times until today. African literary writers write with a borrowed language and like the Yorùbás say, 'the borrowed trousers never fit appropriately, they are either too short or too big'. How do the writers react to this dilemma? Do they accept the situation meekly and use the colonisers' language without any protest? Do they desert the colonisers' language and decide to use their native languages as transmitter of cultural idioms and ideas to their people? Their reactions have been a mix. Some accept the language and try to make something out of it. Some initially write in the foreign languages but later switch to writing in their native languages.

\section{Language Dilemma and Coping Mechanisms}

No man can understand another whose language he does not speak (and 'language' here does not mean simply words, but a man's entire world view) [5].

A language is a marker depicting a person's personality. A person's language, however, is a total summation of a person's being because through it communication takes place and the individual becomes embedded in his/her culture since "language is not inherent in man - the capacity for language, yes; but not language" [5]. Language, however, also serves as a vehicle of cultural transmission since, "any language has a dual character: it is both a means of communication and a carrier of culture" [3]. Taking a mother tongue away from the individual leaves him/her flailing and left at crossroads, neither rooted in the new language opened to him/her, nor well versed in the language and culture that was native to him/her. Having been deprived of expertise in the mother tongue through its suppression in the schools and the learning of the foreign one, the individual is left to use the acquired language, which he/she might never be well versed in like the mother tongue.

The individual then becomes a bilingual or polyglot whose expertise in the language that would have been most appropriate to express his/ her being - the native language - becomes suspect. This predicament is where most African writers who write in the colonisers' language find themselves. There is a need to share their stories with fellow Africans and non-Africans, but the challenge is how to do this effectively. Is it through the native languages spoken by their ethnic group alone or is it through the foreign language that is a world language? In using the foreign language/s, how easy will it be for them to transfer items, idioms and elements rooted in their native culture into the foreign language? What are they expected to do in cases where it is impossible to transfer such elements and idioms? And will the masses who do not speak the foreign language understand what the writer is saying?

Ashcroft, Griffiths, and Tiffin discuss how postcolonial writers answer the questions above when they espouse how postcolonial writing defines itself through two distinct processes, namely [9]:

The first, the abrogation or denial of the privilege of 'English' involves a rejection of the metropolitan power over the means of communication. The second, the appropriation and reconstitution of the language of the centre, the process of capturing and remoulding the language to new usages, marks a separation from the site of colonial privilege. (p. 37)

African writers' defining processes are two-fold. One is accepting the "fatalistic logic of the unassailable position of English in our literature", and deciding to write in the colonisers' languages [5]. The second is writing in the indigenous or native languages.

\section{Accept the Obvious and Appropriate}

African writers need to be rooted in Africa and talk about Africa while giving the African viewpoints because "the African novel has to be about Africa and Africa is not only a geographical expression; it is also a metaphysical landscape - it is in fact a view of the world and of the whole cosmos perceived from a particular position" [5]. This need arises because "there is such a thing as absolute power over narrative. Those who secure this privilege for themselves can arrange stories about others pretty much where, and as, they like" [5]. Only Africans can tell African stories most effectively. They are within the culture, understand the environment and speak the continent's language. As one Yoruba proverb explains, a person's head should not be shaved without his/ her permission; Africans' heads cannot and should not therefore be shaved without their approval or in their absence, which is what telling African stories without their input turns out to be. Being able to tell their stories, however, creates challenges about what languages to use in telling African stories. Is it the native languages, which restricts them to Africa, or is it the colonisers' languages that reach beyond Africa and the writer's own immediate ethnic group?

Achebe and others feel that, taking history and colonialism into consideration, the best option will be to use the colonisers' language. Their argument is that it is not their fault or wish to be saddled with the colonisers' languages, but having been coerced into learning and using the language, it becomes imperative that they must use the language. If the intention is to create cultural content and contribute Africa's quota to the world's cultural productions, then it is acceptable to use the imposed foreign language since, as Achebe puts it, 'there is no other choice [5]. I have been given this language and I intend to use it' ( $p$. 62). This option, however, raises a question, which is: how is the writer expected to use this imposed language? In response, there have been many efforts to indigenise the foreign languages Africans have been forced to use.

Among the Nigerian writers using a foreign language to express the African experiences are Amos Tutuola, Gabriel Okara, the late Ken Saro-Wiwa, Chinua Achebe, the late Ola Rotimi, Wole Soyinka and Femi Osofisan to mention a few. The intention of these and other African writers is to use the foreign language, to express and transmit their cultural experiences and highlight their societal and native environments. This has led to various experiments, which has led to an expansion of the foreign language in a way that it accommodates and reflects the writers' cultures. The writers make the acquired language take on their culture's inherent idioms, colours and linguistic tools like panegyrics, proverbs, riddles, indigenous terms, words and phrases - the way a chameleon takes on the surrounding environment's colour. When this is not enough, they resort to sheer transliteration and wholesale importation of indigenous language, which they then translate. An example is Amos Tutuola. Take the following excerpt from his The Palm Wine Drinkard.

I could not blame the lady for following the Skull as a complete 
gentleman to his house at all. Because if I were a lady, no doubt I would follow him to wherever he would go, and still as I was a man I would jealous him more than that, because if this gentleman went to the battle field, surely, enemy would not kill him or capture him and if bombers saw him in a town which was to be bombed, they would not throw bombs on his presence, and if they did throw it, the bomb itself would not explode until this gentleman would leave that town, because of his beauty [10].

One fact is glaring from his experiment and that is he succeeded in breaking the English language's syntactical rules but also made the language wear Yoruba's garb in order to express Yoruba ideas, idioms and culture. The above excerpt could be written in Standard English as follows:

I find it difficult to blame the lady for following the Skull Man. If I were in her shoes, I would have done likewise. As a man I would have envied him more because if he were to be on the battlefront, it would not have been possible for the enemy to kill him. If a town were to be bombed, the bombers would have postponed bombing until he left the town because of his handsomeness.

This standard rendition, however, does not truly express what Tutuola is saying and how it would be said in Yoruba language. A Yoruba translation of the excerpt shows this clearly to those who know Yoruba.

Nkò lé da obinrin náà l'ébi wípé ó tèlé Agbárí oku ti o jo okunrin gidi náà lo ilé rè. Bín bá j'obinrin, nó tèlé lo àti pé bi n ti j'ókùnrin no jowú rè ju be lo, nítorípé bí okùnrin yi lo s'oju ogun, nitoto awon ota o ni pa tabi mu n'igbekun ati bi awon ti n yan ado oloro ba ri ninu ilu ti won fe so ado oloro si, won ko ni yin ado oloro na titi ti yoo fi fi ilu naa sile nitori ewa re le-ke-n-ka.

This translation shows that Tutuola did an almost word-byword transliteration of Yoruba language into English. For example, Tututola's 'I could not blame the lady for following the Skull as a complete gentleman to his house at all' can be translated into "Nkò lé da obinrin náà l'ébi wípé ó tèlé Agbárí oku ti o jo okunrin gidi náà lo ilé rè." These Yoruba word-by-word translation patterns are almost absent in the standard English translation as the translation of the standard English shows, 'I find it difficult to blame the lady for following the Skull Man' is likely to be, "O soro fun mi lati da obinrin na lebi nitori o tele Okunrin Agbari naa." Another Nigerian writer who tried forcing English to follow the patterns and syntactical rules of his native language is Okara [11]

Explaining his methods in transferring Ijaw idioms and language into English in his novel, The Voice, Okara [11].says:

In order to capture the vivid images of African speech, I had to eschew the habit of expressing my thoughts first in English. It was difficult at first, but I had to learn. I had to study each Ijaw expression I used and to discover the probable situation in it (sic.) was used in order to bring out the nearest meaning in English. (p. 15)

To him the method and the exercise are "a fascinating exercise"; it is, however, burdensome, because the writer must work in two languages in parallel and try to make sense of them while converting ideas, patterns, idioms and linguistic forms from one into the other. A shortcut in this burdensome journey is what other Nigerian writers who accept using the colonisers' language have tried. They write in Standard English but use it in a way that expresses the nuances and embedded meanings of their own indigenous languages. They extend Standard English by adding traditional folklore, imagery, and idioms while making them express peculiarities of their native languages.
Generations of Nigerian writers in English from Achebe, Soyinka, Flora Nwakuche, Tess Onwumere, Ola Rotimi, and Osofisan to present writers like Biyi - Bandele, Ngozi Adichie and Habila Helon, Sefiou Atta have tried this. Their experiments have created a situation where English has been made to express what even native speakers and users of English could not have made the language do. An example will be appropriate here. Osofisan, for example, uses Yoruba riddles, folklores and panegyrics in most of his plays. In Ajayi Crowther: The Triumphs and Travails of a Legend, for example:

EMMA. (Laughing and dodging like the rat) Adiye yee I've got the ransom!

\section{CROWTHER. Then answer quickly! The ball of fire is-?}

EMMA. A ripe palm fruit! No amount of water can quench it!

CROWTHER. Bravo, my daughter! Now it is your turn.

EMMA. Well, emmm ... Right, try this one: I am a black, black charcoal. But when I fall into water, I turn white! Asa mbo! [12].

The above excerpt is a transmutation of Yoruba riddles and storytelling techniques into English. Buried within the excerpt, however, are linguistic and cultural codes that cannot be fully explained or transferred to English. In the same play there are examples of folklore where Osofisan, tells the story of Eyinrola and Ajayi Crowther's panegyric [12]. The writers also use pidgin English as a tool. Pidgin is formed from an amalgamation of words from English and the vernacular to form a new language. The late Ken Saro-Wiwa wrote a novel in pidgin titled Souzaboy. Pidgin represents a lower-class language spoken sometimes by people in the upper class. In From Zia with Love, Soyinka uses pidgin, as he does in some other plays of his.

Detiba: What did I tell you? It's business first and last.

Emuke: Wait small. Tell me how this 'ting dey work

Detiba throws up his hands in despair.

Warder: E get certain 'ting wey you go say; that's all. You tie the bandufu for your waist, or put am somewhere it must touch your body... - if you get oriki, you call all your oriki. Then finally, the place where you wan land. Dat one very important, because if no tell this medicine where it must take you, e fit land you for inside jungle or overseas, or even back inside your enemy hand [13]

Arguably, Nigerian writers' experiments with English deepen and expand the language's capacity more than the way it is being used in its native form. The Afro-European writer must first accept the fact that for reasons of history and education he/she is privileged among his compeers and compatriots. As message transmitter about his society to fellow compatriots and foreigners, the language s/he uses rests on his/ her decision. No matter the choice made, however, the majority of his compatriots or fellow Africans or Nigerians will always be marginalised because they lack the privilege he/she has. There must also be a realisation that whatever language is chosen there will be challenges. To cope with the challenges and transmit the messages should be what the writer devise strategies for.

\section{Highway to Nowhere and the Language Dilemma}

This novelist was born a Yoruba, the ethnic group of Wole Soyinka, the 1985 Nobel Laureate for literature. Like him, he had the rich Yoruba cultural heritage's legacy, but unlike him, he did not have the privilege of a grandfather initiating and immersing me into those cultural traditions and legacies [13]. The novelist's grandfather, unlike 
Soyinka's, was the village's church's Baba Ijó (church's father)'1. The novelist grew up immersed in Christian doctrines, liturgies and rituals instead of being filled with both the pedestrian and arcane aspects of his inherited knowledge, cultural traditions and customs. His lack of initiation into the community's secret cults and groups, because they were labelled paganistic, further pushed him into Christianity. The erosion of his traditional values and culture became consolidated when he started schooling at the age of five. English became the language of instruction and, until present times, his main language of communication and learning. Paradoxically, his own mother tongue has become an appendage and one peripheral to English. He had become a hybrid and the 'half-child at the crossroad', neither well immersed in his cultural heritage nor adept in the language and culture he was forcefully saddled with as a postcolonial child $[14,15]$.

His writings reflected this and language use in Highway to nowhere is a manifestation of this hybridity. Like other African and Nigerian writers, he tried to bend the English language's overbearing and eroding power to his advantage. This has resulted in various devices used in this novel to subvert the overhanging power of English in his life [16]. These devices include epigraphs, proverbs, folktales, divination poetry, footnotes and Yoruba language in instances that it became difficult for him to find appropriate words or phrases in English to express what he wanted to say in his native language.

\section{Epigraphs}

A dictionary of literary terms and literary theories defines an epigraph as "an inscription on a statue, stone or building, the writing (legend) on a coin, a quotation on the title page of a book or chapter and a motto heading a new section or paragraph" [16]. Epigraphs help the writer to quickly summarise the theme/s and focus of his/her writing. A careful reading and interpretation of the epigraph/s gives the reader a quick glimpse into the writer's mind's inner sanctum and perceptions about the piece of writing. Epigraphs in Highway to nowhere are a collection of Yoruba proverbs, songs, biblical passages, one historical quotation and one literary quotation. The majority of these are Yorùbá proverbs and sayings. An epigraph comes at the beginning of every chapter and sub-chapter in the novel. They were teasers meant to whet the reader's appetite while preparing them for what they will be reading. In addition they are a means of transmitting Yoruba culture to both non-Africans and non-Yoruba Nigerians. However, they ended up performing more than the above objectives, as the following analysis will show.

Yoruba cultural items constitute the bulk of the epigraphs, which make a distinction in the novel between a cosmopolitan persona, local or national individuals and serve as a means of differentiation. In Chapter 8 , the epigraphs consist of literary, historical and biblical quotations instead of the common Yorùbá sayings, song or proverbs. We may aver that the introduction of Francis, a cosmopolitan individual, as a character is the reason for this. Francis is well travelled and liberal minded. He has followed paths of atheism to diverse religious beliefs

'The term 'church's father' does not approximate the meaning of the phrase 'Baba ljo'. The Baba ljo and the Iya ljo (church mother) are the two most respected, not necessarily the eldest male and female in the Church. They are patron and matron of the church and highly committed adherents of the church. In some cases they are instrumental in bringing the church into the village or at times, their parents did and they inherited and consolidated the power of the church in the community. The two also serve as elders of the church and the powerhouse of the church establishment. As a result they are usually strict and conservative individuals who repudiate all things 'paganistic and heathenish' - Eugene Achike in Adichie's Purple Hibiscus - and overzealous in the service of their new religion and examples to the lost within the village or community who are still in 'darkness'-Nwoye in Achebe's Things Fall Apart. and through his life's circumstances has had a personal experience with God. An avid reader, who quotes Dostoevsky and the Bible copiously and also a poet, he needed to have epigraphs that fit his cosmopolitan picture. For this reason Flavius Joseph and Somerset Maugham's quotations were used in his chapter.

The preponderance of Yorùbá proverbs, songs and sayings in the epigraphs becomes germane when one realises the proverb's importance in Yorùbá's speech acts and discourse. Proverbs, as Achebe opines, are 'the palm oil with which life's yam is eaten' [17]. The Yorùbás, just like the Ibos, believe in proverbs as the glue that fuses ideas and thoughts together. Yoruba culture attaches great importance to words, speech and utterances because of its perceived psychical and spiritual properties and powers. So, the Yorùbás, "approach speech with deliberate care, taking great pains to avoid careless, casual, or thoughtless statements whose damage might outlast lifetimes". The proverb 'Eyin lòrò; bó bá bale, fifo ni nfo" (Speech is an egg; if it drops on the floor what it does is shatter) bears witness to this concern [18]. The epigraphs also help in categorizing the novel's characters since they give an insight into the character's or narrator's background, as explained in Francis' case above. Other examples include Akanji (Pastor Jude's father), a reverend whose epigraphs were all taken from the Bible, while those of Jude's mother Akanke and Aunt, Foluke were all taken from Yoruba proverbs and sayings to confirm their being Yorùbás not much influenced by either Christianity or modern ideas.

\section{Proverbs}

Those who do not speak a language can never recognise all its proverbs.

Wisdom is learned through the wisdom of others - Yoruba Proverb

Highway to Nowhere contains many proverbs and they play an important role in the novel. Proverbs are "pithy truths", and "nonliteral language". Proverbs are "incisive in propositioning, terse in formulation and deduced for close observation of life, life forms and their characteristics and habits, the environment and natural phenomena and sober reflection on these [18-20]." Proverbs have been part of human existence and culture since the beginnings of time and are ubiquitous in all human societies and cultures [20-23]. Proverbs functions include:

Mirroring the culture, affording members of the society a means of psychological and emotional release through the venting otherwise prohibited expressions, aiding in education and socialisation; and... maintaining conformity to accepted patterns while also validating institutions, attitudes and beliefs. [19].

Proverbs are also 'aesthetic' and use "all of the devices we commonly associate with poetry in English: meter, binary construction and balanced phrasing, rhyme, assonance and alliteration, conciseness, metaphor and occasional inverted word order and unusual construction". Proverbs by their nature thereby contribute to greater understanding among human beings and build a communal ethos. The proverb's nature and importance make it useful in Highway to nowhere. For a novel set in Yorubaland reflecting societal culture and striving to validate Yoruba institutions, attitudes and beliefs, as Bascom postulates above, the novel's use of proverbs is appropriate.

Proverbs in Highway to nowhere when used as an epigraph serve as a means of structuring or summing up the tale or story in the subchapter. They also give insight and interpret actions and events within the sub-chapters. By so doing, they add meanings to the story being told. 
In the second sub-chapter of the novel's Chapter One, titled the flight, with Pastor Jude as the narrator, the epigraph is a Yoruba proverb: 'Eda to m'ola ko si, to dia feni ti o ni d'ola; to n d'osu mefa'. This translates as, 'nobody knows tomorrow; the divination for the person who won't last tomorrow but is planning for the next six months.' In this subchapter pastor Jude reminisces at the airport lounge on his relationship with his wife. During this time, he met members of his church and invited the pregnant new bride to the church's Pregnant Women's Counselling Group, which he conducts every Thursday. He also made an arrangement in his mind to call his family in Lagos and visit them the following week. All these plans came to nought because he lost his life in a plane crash the same day. The epigraph, therefore, summarised what happened in the sub-chapter because the pastor was not thinking of death while making those plans. The two proverbs used on page 54 , 'oro ki sa wuwo ka fobe bu' (words cannot be too heavy that we cut it with a knife) and 't'ibi t'ire la da ile aaye' (the world is created containing good and evil) summarised the kernel of Chapter Three's third sub-chapter. In this sub-chapter, Foluke, Pastor Jude's aunt is afraid to tell her brother Akanji, a Reverend, the need for traditional rituals and sacrifices for the newly born Jude. Her brother used the first proverb in allaying her fears by pointing out she needs to give the message. Proverbs, such as those in the above examples, give added meanings and explain incidents and events. The proverbs in the novel reflect Yorùbás discourse patterns and tools.

\section{Folktales and divination poetry}

Nigerian writers use oral literature elements in their writing. One outstanding example is Amos Tutuola whose works, My life in the bush of Ghosts and Palmwine drinkard, were based on Yoruba folktales. Folktales and divination poetry are forms of Yoruba oral literature and verbal arts. Diviners using special sight, special acuity or clairvoyance, which are enhanced through rituals and medicine, foretell the future or give solutions to people's problems [24-28]. The diviners use objects and other paraphernalia and, in the case of Yorùbás, stories and texts called Odu Ifá. Though there are folktales in Ifá verses, the Babaláwo (the diviner) is not expected to tell folktales but Ifa's revealed truth [19]. This is reflected in Highway to nowhere. On pages 48-49, Foluke, the pastor's aunt, heard Baba Fagbemi's recitation of one of the Ifá corpus, Edi Meji. The recitation uses a folktale to tell the likely end of the newborn babe. This, and the use of folktales in the novel, is a fall back to the novelist's culture in order to further his second language use. One other tool he used as the novel's language coping mechanism is footnotes.

\section{Footnotes}

Highway to Nowhere has 47 footnotes, yet it is a novel, not a textbook. Though they explain points or ideas unknown to readers or clarify confusing issues, footnotes may be intrusive or distractive for the reader [29]. Why load a novel with forty-seven footnotes? Of what use are they? Are they really necessary? In Highway to Nowhere they are necessary because of the novel's pedigree. The novel, written as creative component of the novelist's $\mathrm{PhD}$ in creative writing, is written in a cultural milieu different from the author's own. There were challenges encountered transferring Yoruba cultural idioms and concepts into a non-Yoruba cultural climate as earlier stated in this paper. The difficulties were in language, perception, beliefs and culture and they were interrelated and intertwined.

Along with epigraphs, Highway to Nowhere also used folktales as explanatory tools. For example one of the epigraphs, a Yoruba proverb, ' Bi ewe ba pe l'ara ose a d'ose, b'obinrin bá pe n'ile oko a d'aje (When the soap wrapping leaf stays too long with the soap, it becomes soap; when a woman stays too long in her husband's house she becomes a witch) impressed non-Yoruba readers as being unusual in its meaning. Though there was no footnote for this, explanations of the proverb's varied meanings had to be made to them that a woman married for a long time to a man becomes so familiar with him that relations and onlookers will term her a witch because of her ability to predict her husband's actions, behaviour or idiosyncrasies. The same situation occurs on the hawk and the duck's folktale the novelist used in explaining Fúnmiláyò's final act in the novel (Highway to Nowhere, pp. 382-383). There were queries about the relevance of the tale to the novel. The tale differentiates between a loud and a silent person. The loud or the talkative person is predictable while the quiet or silent person is unpredictable. One is unable to decipher a silent or quiet person's mind. Fúnmiláyò's silence and behind-the-scene actions were unknown to her husband and her husband's relations and this made it impossible for her to be checkmated.

Highway to Nowhere depicts Yoruba culture though it is written for both Yoruba and non-Yoruba readers. Efforts were made to limit the number of cultural references but many were pertinent to the novel. The challenges in using them, however, were in being able to translate them for a non-Yoruba in a way that s/he will get the embedded meanings in these cultural practices. In writing the novel, the novelist found this to be a big challenge because there are instances where a deeper exploration of these cultural items will be confusing. An example will suffice here. Footnote 3 for Aisiki is explained as a person's good fortune is brought or predestined from heaven. However, it means more than this because Aisiki to the Yorùbás summarises an individual's total essence. It goes beyond good fortune, because it is the person's totality and essence of being. When Aisiki is taken from an individual, the person becomes an empty shell without his/her true essence, or as the Yorùbás will put it an Oku Aye, that is, a living dead or walking corpse. It is not only that the Yorùbás believe each individual comes with his/her essence from heaven, but also they believe that this can be tampered with, taken from someone or even transferred to another person through occult means and the work of malevolent spiritual entities. Explaining in-depth what Aisiki means entails conceptual challenges and transference gaps. For example, it is possible to write Aisiki's meaning contextually into the novel such as,

The Yorùbás believe that an individual's good fortune, their Aisiki, is brought from heaven and that it can be stolen or used by other people. Since I was becoming richer and more successful, rumours started circulating that I killed my two husbands in order to use their Aisiki. (Highway to Nowhere, p. 22)

Though a non-Yoruba reader will be able to have an understanding of what Aisiki means through the above but the below footnote, extends the meaning thereby deepening the understanding of the word-Aisiki - for non-Yorùbás. Highway to Nowhere's footnotes exemplified some of the cultural ideas non-Yoruba readers will not be used to but even in translation many embedded meanings and aspects had to be simplified. The dilemma of what to add or deduct in transferring meanings of cultural acts, ideas practices were not only baffling for the novelist but placed him on a tight rope walk. He has to juggle between explaining the ordinary meanings of the cultural items in context within the novel and writing bulky footnotes that will become a source of distraction and intrusive to the readers' enjoyment and understanding of the story he was telling. He finally decided on using footnotes. How well he has used these footnotes as negotiating tools in conveying the depth of his language and culture is explored next. 
Áisikí: An individual's good fortune, which the Yorùbás believe, is brought from heaven. They also believe that spirits, witches, wizards or people through medicine or the occult could change a person's aisiki, and that a person's aisiki could be stolen or used by other people. Hence the prayer, "k'araye ma pa kadara mi da, ki aye ma lo aísikí mi. (May human beings not change my destiny, and may they not use my good fortune) (Highway to Nowhere, p. 26)

\section{Footnotes as negotiating tools}

How do footnotes transfer cultural ideas? Can they bridge the gap between cultures, meanings and levels of understanding? Footnotes are used as a means for transferring meanings and a tool of clarification. The assumption behind their use is the explanation of what remains unknown to a reader, or what requires clarification or exemplification of specific idea/s to a reader. Footnotes in Highway to Nowhere are categorised into those based on cultural insight, proverbs and wise sayings, citations, pidgin-derived terms and common Nigerian terms that the novelist had assumed would be known to any reader until they were queried and he had to explain. One of the cultural beliefs used in the novel that he needed to explain through footnotes 9 and 11 is the summary of the Ese-Ifa (Edi Meji) that unless the person whose akosejaye is divined performs the necessary etutu (rituals and sacrifices), the person will be well known, rich and become important but will die an untimely death. Yorùbás will ascribe Jude's death in the plane crash in the novel to his father's inability to perform the etutu because of his Christian beliefs. This belief is understandable to Yorùbás but is likely to be confusing to a non-Yoruba who will be unable to relate to how the inability or refusal to carry a metaphysical injunction given when a baby is less than two weeks old could lead to the death of the baby now a man, forty-five years later.

The decisions on what to footnote and what not to include were determined by the various queries by non-Yorùbá's and the extent of what to explain was the writer's decision. Tension existed in determining how far he can go when explaining one concept or the other. Footnote 20-Aransi for example is explained in the footnote thus:

Aransi: Types of Yoruba occult practice in which words, curses or animals like snakes or other dangerous animals (or in the case of a hunter, mistaking a human being for an animal) is sent to a person through remote means and the person carries out such injunctions without knowing why. This is usually achieved through word of mouth. Asasi is almost like aransi but the difference is that in asasi the person targeted would not realise what is happening until after the event. For example, a man may be called to kill his wife or do harm to his children and he would carry it out without understanding or knowing why and will greatly regret the action when his vision clears.

What he left out of the footnote above includes explanations about asasi, asise, asete, apeta and anperi. All these are various forms of Aransi. A more comprehensive explanation of Aransi would have been as follows,

Aransi: That which is sent to an individual and expressed in curses, utterances, masks, dangerous animals like snakes, insects like bees, puppets or effigy or at times unexplainable abnormal behaviour. Aransi is suspected when a perfectly normal person behaves exceedingly different from the normally consistent manner to which the man had been known for. Yorubas will explain such that someone somewhere had uttered some words that remotely controlled such a person to take such action. In cases where puppet, effigy, dangerous animal or insects or daemons is sent, the individual will be the only person seeing those dolls or daemons or in case of animals or insects, they will materialize where they are never expected to be. These stories are not schizophrenic attacks or that of split personality disorders because cases where are individuals have been crying out of being beaten by unseen people or forces and later welts were seen on their bodies had been documented. Aransi can be manifested through asasi, asise, asete and apeta.

Asasi is when the individual's behaviour is affected through occult or deep hypnotism and the person casting this spell on the individual does not need to see or be in the same place with the individual being ordered to do harmful actions to himself/herself or other people. A scene in film 'The Devil's Advocate' where a Haitian performed some rituals by sticking pins into a bull's tongue thereby making a court witness to become dumb in court thereby truncating the case will be a good example of such as practised in the Diaspora. In Yorubaland, the person may even vomit blood the more he/she tries to talk.

Asise is when through occult and medicine a person is made to start misbehaving and becoming obnoxious most especially to those close to $\mathrm{him} / \mathrm{her}$ and those who loves him/her or are in position to help him/her. This stage will lead to Asete where s/he becomes hated and ostracised by all s/he comes across. People will hate the person without any tangible reason. This phase of the person's life will be totally different from the life the individual had been living before. In most cases this type of Aransi is sent to responsible people or those in authority who are blocking evil people from achieving their aims. Apeta is where a person's Ori or Eda is called metaphysically most times when the person is asleep or in the night. The person answers from sleep and die.

The explanations above as a footnote to explain just a reference to the concept on the novel's page 47 would have been a source of distraction to the reader. Highway to Nowhere is a novel and not a textbook on Yoruba traditional religion and beliefs. The cultural items were meant to be side dishes and not the main dish. This is what happens in translation and this deprives readers of deeper knowledge. If Highway to nowhere had been a novel meant for the general public in its present form and not for a doctoral examination, the novelist would not have used so many footnotes. Maybe he would have placed a glossary at the novel's end. The footnotes in the present version, however, came out of comments, questions and the need to explain areas that his Supervisor deems unclear. Firstly, this exercise helped him realise the need to find easier ways of transferring his cultural concepts to others who are not from his background. Secondly, it shows the differences existing in cultural perceptions and worldviews of different people when they are of differing cultural backgrounds. This in turn makes him think of devising means of transferring those cultural ideas.

\section{Narrative Devices}

There are many devices through which novels are narrated. While there is little magical realism and a little deviation from linear narrative structure, Highway to Nowhere uses some other devices to impose order on the narration of the story and the novel's structure. Time and period were used to create a linearity in the story telling. The many narrative devices were meant to add variety to the narration and tone down the monotony of reading through many first persons' points of view and changing from one story to the other. Devices like E-mail (pp. 266-269), cellphone SMS or texting (p. 294); the epistolatory style in chapter 19, inner monologues (pp: 34, 64, 142, 143, 152, 193, 264-265, 271-272, and 275-276) and cinematic framing help in achieving this aim.

Epistolatory style has been used in Samuel Richardson's Clarissa, 
Mariam Ba's So long a letter, Finuola Dowling's What poets need and A.S Byatt's Possesion. In these examples, the novels were based on letters written to a particular character and through the letters, narration occurs. In Possesion there was a twist in the sense that instead of letters being exchanged, a dead writer's letter became the investigating trigger used in exhuming the dead writer's life and the politics involved in academic works on him. In Highway to Nowhere, the letters from Pastor Julius, a co-pastor and intimate friend of Pastor Jude, to Bisoye are used to inform the readers about reactions from the church, church members, church officials and the depth of church politics after Jude's death. The correspondence between Pastor Julius and Bisoye gives an insight and information about Jude's death and the conditions surrounding them had been treated by the churh he ministered while alive. Also, Jude's vision and ministry in helping the needy personally and the opposition against his carrying out these acts are revealed through the letters while giving us a new insight into his character. There is also a revealing of the perceptions of his church members concerning the nature of his death and rumours and facts of his death. The experiment with E-mail, and SMS or cellphone texting in the novel were attempts at locating the story in the present information age. Language reconstruction and concise transfer of symbols and words seen in E-mail and SMS reflect present use of them in today's communication.

\section{Conclusion}

Another of the novel's narrative device is the use of cinematic framing. Incidents and situations in Highway to Nowhere are created following the pattern of presentation in cinematography's narration. A cinema frame or film's unit of narration consists of a character, a location and action. The changing of one of these elements brings a new frame into existence. The frames are then joined together to give a total picture of the story being told. In Highway to Nowhere, the constant shifting of the three elements in each narrator's story creates a sort of new cinematic frame. The addition of these frames at the end gave us the novel's story and a framed picture of Pastor Jude the novel's absent main hero. At the beginning of the novel however, it seems one is reading an almost disjointed and unrelated stories but at the end of the novel these seemingly unrelated narrations gave a complete story and a clear picture.

Abrams and Harpham, explaining Bakhtin's dialogic criticism, state that, "a person's speech does not express a pre-existent and autonomous individuality; instead, his or her character emerges in the course of the dialogue and is composed of languages from diverse social contexts" ( $\mathrm{p}$. 77). In order to actualise this type of dialogue, literature, including most novels, clothes their narrators' utterances in circumstances, in descriptions of narrators' psychological states, in the environments the narrators or characters occupy and in the interplay between the narrators as characters or interlocutors. Highway to Nowhere, however, deviates a bit from this norm through the use of what can be termed 'naked dialogue'. This is where dialogue is stripped of all the markers that help fixate them in the readers' minds. Markers such as narrators or characters' accoutrement, the location, the circumstances the characters are in, authorial comments and the characters' emotional states. These are sometimes reflected in 'he sighed deeply' or 'she wondered' or in Dowling's (2007, p. 155) example, "Beth said something that I don't think she intended as hurtful. She said, 'Theresa is nice to everybody, isn't she?" and so on. Dialogue in Highway to Nowhere comprises sequences of two people talking and the readers are asked to fill in all other elements of the conversation in their minds.

The multiple points of view, epistolatory technique and experiment with e-mail, texting, inner monologues, cinematic framing and 'naked dialogues' were attempts to cope with the language dilemma the novelist faced in writing this novel. It is his attempt to introduce new ways of using English in telling a story that is fully based in his culture to those who are not from his cultural background and whose language he used in telling his story.

\section{References}

1. Samovar LA, Porter RE, Jain NC (1981) Understanding intercultural communication Belmont California: Wadsworth Publishing Company.

2. Greenberg JH (1971) Language culture and communication: Essays selected and introduced by Anwar S Dil Stanford California: Stanford University Press.

3. Ngugi WT (1996) Decolonising the mind: The politics of language in African literature Portsmouth New Hampshire: Heinemann Educational Books Inc.

4. Vaughan VM, Vaughan AT (2005) The Tempest London: Thomas Learning.

5. Achebe C (1975) Morning yet on creation day. London: Heinemann Educational Books.

6. Memmi A (1990) The colonizer and the colonized London: Earthscan Publications Ltd.

7. Zabus C (1991) The African Palimpsest: Indigenisation of language in the West African Europhone novel Amsterdam-AtlantaGA: Rodopi, p: 224.

8. Hammond D, Jablow A (1992) The Africa that never was Prospect Heights Illinois: Waveland Press.

9. Ashcroft B, Griffiths G, Tiffin H (2002) The Empire writes back London Routledge.

10. Tutuola A (1953) The palm-wine drinkard and his dead palm-wine tapster in the Deads' Town London: Faber and Faber.

11. Okara G (1963) African speech... English words Transition 10: 15-18.

12. Osofisan F ( 2006) Ajayi Crowther: The triumphs and travails of a legend Ibadan Nigeria: Bookcraft Ltd.

13. Soyinka W (1991) Isara: a voyage around "Essay", London: Minerva.

14. Bhabha H (1994) The location of culture New York: Routledge Classics.

15. Soyinka W (1963) A dance of the forest London: Oxford University Press.

16. Cuddon JA (1991) A dictionary of literary terms and literary theory Oxford: Basil Blackwell Ltd.

17. Achebe C (1965) Things fall apart. London: Heinemann.

18. Owomoyela O (2004) The good person: Excerpts from the Yoruba treasury.

19. Kurien J (1998) Traditional ecological knowledge and ecosystem sustainability: New meaning to Asian coastal proverbs Ecological Applications.

20. Katz AN, Ferretti TR (2001) Moment by moment reading of proverbs in literal and non- literal contexts Metaphor and Symbol 16: 193-221.

21. Adewoye $O$ (1987) Proverbs as a vehicle of juristic thought among the Yorùbá Obafemi. Awolowo University Law Journal, pp: 3-17.

22. Odebunmi A (2006) A pragmatic reading of Ahmed Yerima's proverbs in Yemoja Attahiru and Dry Leaves on Ukan Trees Intercultural Pragmatics 3 . 153-169.

23. Pasichiniuk I (1999) Omens proverbs and tales: Genre fluidity in folklore Seefa 4: 10-15.

24. Bascom W (1980) Sixteen Cowries: Yoruba divination from Africa to the New World Bloomington: Indiana University Press, p: 790.

25. Douglas M (1957) Animals in Lele religious symbolism implicit meanings: Essays in Anthropology London: Routledge and Kegan Paul.

26. Erivwo S (1979) Epha divination system among the Urhobo of the Niger Delta African Notes 8: 21-25.

27. Horton R (1964) Kalabari diviners and oracles ODU 1: 3-16.

28. Meek PM (1991) African divination systems: Ways of knowing Bloomington: Indiana University Press.

29. Hartley J (1999) What do we know about footnotes? Opinions and data. Journa of Information Science 25: 201-220. 